ROCZNIKI KULTUROZNAWCZE

Tom/Vol. XI, numer/number 4 - 2020

DOI: http://doi.org/10.18290/rkult20114-3

MAŁGORZATA KOWALEWSKA

\title{
ZE STAREGO ŚREDNIOWIECZA DO NOWEGO
}

\author{
MIKOŁAJA BIERDIAJEWA DIAGNOZA SYTUACJI \\ - TYTUŁEM WSTĘPU
}

„Klasyczny podział dziejów na trzy okresy: starożytny, średniowieczny i nowożytny jest przeżytkiem. Usuniemy go wkrótce $z$ naszych podręczników szkolnych. Historia współczesna kończy się. Wchodzimy w nową nieznaną Erę, której niedługo trzeba będzie wynaleźć miano. Wyszliśmy właściwie poza ramy naszej epoki. [...] Ludzie umiejący przewidzieć przyszłość mieli od dłuższego czasu wyraźną świadomość nadchodzących zmian. W spokojnym i na pozór ugruntowanym życiu europejskim mnożyły się duchowe zapowiedzi przełomu. Źródłem wszelkich przemian w zewnętrznej rzeczywistości dziejowej są zmiany w sferze duchowej. Tam też należy szukać zapowiedzi tych zmian. Pierwej bowiem zmienia się coś w duszy człowieka zanim nastąpi to $\mathrm{w}$ świecie zewnętrznym, i zanim zniszczały wartości historyczne współczesnego człowieka, nastąpiło w jego duszy załamanie. Zostały zburzone pewne pierwiastki. Fakt tedy wejścia naszego świata w fazę rozkładu nie powinien dziwić tych, którzy umieli obserwować, poprzedzające ten rozkład, zjawiska duchowe.

Odwieczne fundamenty Europy chwieją się. Wszystko, co dotychczas było uświęcone zwyczajami, zmienia się. Drga to, co uchodziło za nienaruszalne. Nigdzie nie ma pewnego gruntu pod nogami: wszystko jest podminowane. W tych warunkach wszelkie przewroty są możliwe. Stary świat Europę, wypiera nowy świat - daleki Zachód, Ameryka i daleki Wschód tajemnicza i groźna Japonia oraz Chiny. A w łonie starej Europy podnoszą

Dr hab. MaŁgorzata Kowalewska, prof. UMCS - Uniwersytet Marii Curie-Skłodowskiej w Lublinie, Wydział Filozofii i Socjologii, Instytut Filozofii, Katedra Etyki; e-mail: malgorzata elzbieta.kowalewska@poczta.umcs.lublin.pl; ORCID: https://orcid.org/0000-0002-2691-1318. 
się rozkiełznane moce. Burzą fundamenty, na których stoi jej zgrzybiała kultura, związana nierozerwalnie z klasyczną starożytnością.

I tylko człowiek krótkowzroczny może nie widzieć, że cywilizacja europejska znajduje się w fazie szczytowego kryzysu, o znaczeniu wszechświatowym. Historyczne następstwa tego przesilenia gubią się w nieodgadnionej pomroce nadchodzących wieków. W tych warunkach tylko naiwne i powierzchowne umysły mogą się łudzić, że uda się powstrzymać środkami zewnętrznymi ten zawrotny pęd grzesznego świata ku katastrofie. [...] Wchodzimy w Nieznane i nawet Nieodgadnione [...] Przyszłość jest mroczna [...] Optymistyczne [...] zapewnienia o tym, że każda przyszłość musi być lepsza, radośniejsza i piękniejsza od przeszłości, rozwiały się w zetknięciu z dziejową prawdą. Dziś nareszcie zaczynamy rozumieć, że wszystko, co najlepsze i najpiękniejsze, znajduje się nie w przyszłości, ale w... wieczności. Przeszłość początek swój bierze z wieczności. Wieczność tworzy i przeszłość, i przyszłość”"

Artykuł ten zaczynam obszernym cytatem zaczerpniętym z szeroko znanej i bardzo cenionej książki jednego z najwybitniejszych rosyjskich filozofów Mikołaja Bierdiajewa. Książka, która została napisana w 1924 r., nie straciła na aktualności dzięki (co podkreśla we wstępie do pierwszego polskiego wydania tej książki jej tłumacz Marian Reutt) wybitnej intuicji historycznej Autora, trafnej ocenie procesu dziejowego i tego, co dawne epoki istotnego do tego procesu wniosły, oraz tego, co przynosi przyszłość. Czas nie zdezaktualizował myśli Bierdiajewa, a wręcz przeciwnie - dostarcza coraz więcej argumentów potwierdzających ich słuszność. Nawiązanie do tej książki jest oczywiste nie tylko ze względu na tytuł tego numeru Roczników Kulturoznawczych, ale także ze względu na to, że jej Autor uważa, iż prawdziwy renesans, którego „pierwsze odruchy były całkowicie chrześcijańskie”, narodził się w głębi Średniowiecza, ujawniając swoje duchowe oblicze w XII i XIII wieku, a ten artykuł jest poświęcony właśnie jednej z wybitnych osobistości kultury XII wieku - Hildegardzie z Bingen, która obecnie ze „Starego Średniowiecza” wraca w „Nowe Średniowiecze”, postulowane dla naszych czasów. Nie będę, naturalnie, omawiać książki Bierdiajewa, wspomnę jedynie, że nie nawołuje on do „powrotu do średniowiecza”, co jest przecież niemożliwe, ale do tego, by dążyć do „nowego średniowiecza”, czyli do odzyskania prawdziwie chrześcijańskiego, głęboko duchowego wymiaru życia i, między innymi, odrzucenia tego, co on nazwał „mamonizmem”.

\footnotetext{
${ }^{1}$ Mikołaj Bierdiajew, Nowe Średniowiecze, thum. Marian Reutt, Meandry kultury (Kraków: Wydawnictwo Vis-à-vis Etiuda, 2019; przedruk za wydaniem: Poznań: Towarzystwo Wydawnicze „Głosy”, 1936), 13-14.
} 


\section{ODKRYWANIE TWÓRCZOŚCI HILDEGARDY Z BINGEN}

Szerokie i stale wzrastające zainteresowanie tak osobą Hildegardy z Bingen, jak też jej szeroko rozumianą twórczością uważam za jeden z przejawów tendencji do odzyskiwania duchowego wymiaru życia i tęsknoty za „Nowym Średniowieczem”. To wkroczenie Hildegardy do kultury współczesnej odbywa się $\mathrm{w}$ wielu obszarach. Zostało zapoczątkowane badaniami filologiczno-historycznymi podjętymi w końcowych latach XIX wieku i na początku XX przez badaczy spuścizny autorów średniowiecznych i wiązało się z rozwojem mediewistyki, ale także humanistyki współczesnej. Jako pierwsi spuścizną Wizjonerki zainteresowali się bp Jean Baptiste Pitra, Ildefons Herwegen i Johann Philipp Schmelsseis. Z czasem grono badaczy poszerzało się, co przyczyniało się do wzrostu zainteresowania tak jej osobą, jak twórczością. Odkrywane pisma Hildegardy były opracowywane i wydawane w znamienitych seriach wydawniczych: Patrologia Latina, Analecta Sacra i w Corpus Christianorum. Continuatio Mediaevalis. Jako pierwszy dzieła Hildegardy wydał Jacques Paul Migne w 197 tomie serii Patrologiae cursus completus. Series Latina (Paryż, 1855), a następny był Jean Baptiste Pitra, który opublikował je w VIII tomie serii Analecta Sacra (Monte Cassino, 1882; wydanie drugie: Farnborough, 1966), a z końcem XX wieku od 1978 r. zaczął je wydawać Brepols w serii Corpus Christianorum. Continuatio Mediaevalis. W tej serii wydano „trylogię wizyjną”, czyli: Scivias, Liber vitae meritorum, Liber divinorum operum, oraz bogaty zbiór epistolograficzny i hagiografię poświęconą Hildegardzie Vita sanctae Hildegardis. Jeśli chodzi o pisma przyrodoznawcze, to w 1903 r. Paulus Kaiser wydał Causae et curae, a od 2010 r. jest dostępna wydana krytycznie Physica. Wraz z kolejnymi edycjami zaczęły się pojawiać tłumaczenia tych pism z łaciny średniowiecznej na języki nowożytne. Wydane pisma mogły stać się przedmiotem, licznych już dziś, prac systematycznych z zakresu teologii, historii filozofii, historii sztuki, w tym muzykologii, epistolografii, a także historii medycyny.

Pisma Hildegardy zachowane w rękopisach są pięknie i bogato ilustrowane, co czyni z tych rękopisów prawdziwe dzieła sztuki. Jest to sztuka mająca nie tylko wartość estetyczną, ale głównie ideową, owe bowiem ilustracje są wspaniałym przykładem języka ideograficznego, którym przemawiają plastyczne dziedziny humanistyki. Wśród nich znajdują się takie, których przekaz jest bardzo złożony, „streszczają” one bowiem obszerne doktryny oraz ważne dla ówczesnej kultury idee, jak na przykład doktrynę mikrokosmizmu. Ilustracje te są cennym przedmiotem badań dla historyków 
sztuki i badaczy kultury. Dzięki współczesnym edycjom pism Hildegardy oraz innym książkom, w których są zamieszczane, przekonują wielu do dawnej sztuki, sztuki z czasów, w których jeszcze nie odkryto perspektywy zbieżnej, ale która stanowi ważny etap w rozwoju języka ideograficznego.

\section{ZNACZENIE BEATYFIKACJI HILDEGARDY I JEJ WŁĄCZENIA DO GRONA DOKTORÓW KOŚCIOŁA}

Bardzo ważnym etapem w historii powrotu Hildegardy do świadomości naszych czasów było potwierdzenie jej świętości przez papieża Benedykta XVI nulla accedente formali definitiva, nullis iudicialibus processibus, nullisque consuetis caeremoniis adhibitis, czyli w ramach tzw. konsekracji równoważnej, polegającej na potwierdzeniu świętości osoby, która już wcześniej była przez wiernych otaczana kultem, na podstawie cudów za jej pośrednictwem, potwierdzonych w świadectwach historycznych, ale bez procesów formalnych i zazwyczaj przeprowadzanych procesów prawnych ${ }^{2}$. Następnym krokiem było włączenie Hildegardy, jako czwartej kobiety - obok św. Katarzyny ze Sieny, św. Teresy od Jezusa i św. Teresy z Lisieux, do grona Doktorów Kościoła, także przez papieża Benedykta XVI. Tym samym Benedykt XVI wskazał Hildegardę jako nauczyciela wiary dla Nowego Średniowiecza, które - być może - nadejdzie w XXI wieku, jako ratunek przed coraz wyraźniej widocznymi tendencjami prowadzącymi do upadku cywilizacji i kultury, którą nazywamy „naszą”, a widocznymi w obszarze wiary, moralności i sztuki. W związku z tym należy przypomnieć, że Hildegarda głosiła konieczność powrotu do źródeł wiary, powrotu do rozważania Tajemnicy Trójcy Świętej i Tajemnicy Wcielenia, częstej lektury Pisma Świętego oraz studiowania pism Ojców Kościoła. Wzywała też do dbałości o czystość wiary, jej obrony i do odrodzenia żarliwości życia duchowego oraz czystości życia osób duchownych. Liczne ilustrujące tę postawę przykłady znajdują się w jej pismach zarówno głównych, tworzących tak zwaną trylogię wizyjną, jak i w pismach mniejszych. W tym miejscu przywołam niewielkie, ale niezwykle interesujące dziełko Hildegardy, będące komentarzem objaśniającym tekst jednego $\mathrm{z}$ pierwszych sformułowanych wyznań wiary chrześcijańskiej, czyli do przypisywanego św. Atanazemu Symbolu zwanego Qui-

\footnotetext{
${ }^{2}$ Zob. Blanka Szymańska, „Przedmowa” do: Hildegarda z Bingen, Wyjaśnienie Symbolu Św. Atanazego, wstęp, przekład i oprac. Małgorzata Kowalewska, Hildegardiana - opera minora (Ełk: Adalbertinum, 2015), 13.
} 
cumque $^{3}$. Dziś warto było by przypominać oba te teksty: zarówno Quicumque Atanazego, jak i Explanatio Symboli sancti Athanasii Hildegardy. Jest w nich bowiem wyłożona i przypomniana prawda o Trójjedyności Boga, która jest wielką Bożą tajemnicą, a zarazem podstawową prawdą wiary katolickiej. Jest to prawda, po której mniej lub bardziej wyraźnym zakwestionowaniu wiara ulega przemianie i staje się nie tą, którą powinna pozostać. Tekst Quicumque jest podzielony na dwie części, z których pierwsza jest poświęcona wykazaniu prawdy o Trzech Osobach Bożych i o jedności ich natury, a druga ukazuje Boskość drugiej Osoby Trójcy oraz omawia jego naturę Boską i ludzką. Do tych prawd odnosi się w swoim Explanatio św. Hildegarda, która swoje objaśnienie Symbolu atanazjańskiego przygotowała do celów dydaktycznych. Chciała tym tekstem uczynić bardziej zrozumiałymi trudne zagadnienia wiary, a tym samym uprzystępnić jej istotę. Zadedykowała go mniszkom z klasztoru, któremu przewodziła, a które nie zawsze były zdolne do pojęcia tak subtelnych idei, dlatego w tej próbie wyjaśnienia Hildegarda posłużyła się bardzo ciekawymi przykładami pewnych zjawisk obserwowalnych w świecie (na przykład zjawisko płonącego ognia), pewnych procesów (na przykład procesu wykuwania żelaza), codziennych zajęć (jak na przykład wiązanie snopków na polu) oraz odwołała się do wniosków wynikających z autorefleksji, czyli poznania naszej ludzkiej natury. Uważam, że ten tekst Hildegardy może stanowić także dziś istotną pomoc w próbie zrozumienia lub nierzadko przypomnienia podstawowej prawdy wiary. Przypomina on, czym jest człowiek i na czym polegają jego główne błędy w myśleniu o sobie, co także dziś powinniśmy sobie uświadamiać. Hildegarda przypomina, czym jest Kościół sam w sobie i czym jest Kościół dla nas. Znajdziemy tu także słowa upomnienia skierowane do duchownych - słowa, które - ze względu na niektóre dzisiejsze problemy Kościoła powinny być wypowiedziane także dziś: „Ci spośród was, którzy kierujecie ludem [...] zwróćcie się ku niewidzialnemu Bogu, którego nikt nie może pokonać ani zobaczyć cielesnymi oczyma. A ponadto zważcie, w jaki sposób kierujecie waszymi posiadłościami, które otrzymaliście od Niego, ponieważ w

\footnotetext{
${ }^{3}$ Przekonanie, że autorem tego Symbolu wiary, zwanego Symbolum Athanasianum lub Quicumque (od pierwszych jego słów: „Quicumque vult salvus esse”), jest św. Atanazy, funkcjonowało od VII wieku do XVII, czyli także w stuleciu, w którym żyła Hildegarda. W XVII wieku rozpoczęły się badania krytyczne, które zakwestionowały autorstwo tego Symbolu wiary i wskazywały innych możliwych autorów: Wincentego z Lerynu, Hilarego z Poitiers, Ambrożego z Mediolanu, Cezarego z Arles, Fulgencjusza z Ruspe. Współcześnie uważa się, że Atanazjański Symbol Wiary powstał w latach 430-542 na terenie Galii lub Hiszpanii. Zob. Lucjan BALTer, Atanazjański symbol wiary, w: Encyklopedia katolicka, t. 1 (Lublin: Towarzystwo Naukowe KUL, 1973), kol. 1025; SzYMańsKa, „Przedmowa”, 18.
} 
Jego imię jesteście obdarzani wielkim szacunkiem. I tak kierujcie ludem, abyście się wobec Niego nie czerwienili w dniu sądu z powodu waszego zarządzania. Strzeżcie się także, abyście nie byli tak zaabsorbowani ohydnymi, budzącymi wstręt pożądaniami cielesnymi i światowymi rozkoszami, że jedynie z trudem «jednym okiem» możecie się zajmować niebiańską nauką"4.

\section{HILDEGARDA W NURCIE HUMANIZMU CHRZEŚCIJAŃSKIEGO XII WIEKU}

Należy też pamiętać o humanizmie dawnego średniowiecza, który w XII wieku przejawiał się między innymi intensywnymi studiami nad literaturą starożytną prowadzonymi w szkole w Chartres, a także nowymi ideami przenikającymi kulturę. Wśród tych idei wymienię wzrastające znaczenie kultu Człowieczeństwa Syna Bożego, wynikającą z tego ideę braterstwa Chrystusa i żyjących na ziemi ludzi oraz naśladowania Chrystusa w jego życiu ziemskim, a także, związaną $\mathrm{z}$ wymienionymi, ideę akcentowania ludzkich wymiarów macierzyństwa Maryi, co między innymi uwidaczniało się w sztuce figuratywnej w postaci motywu Maryi karmiącej (Maria lactans). Wraz z tymi ideami pojawiła się tendencja do uwzględniania cielesnego aspektu natury ludzkiej, a także afirmowania w życiu zasad umiaru i równowagi, w miejsce restrykcyjnych praktyk ascetycznych. Przykładem takiego podejścia są mądre słowa Hildegardy skierowane do Elżbiety z Schonau, skłonnej właśnie do nadmiernej ascezy, oraz wskazówki zawarte w objaśnieniu do Reguły św. Benedykta.

$\mathrm{Na}$ ten ostatni tekst Hildegardy chcę zwrócić szczególną uwagę Czytelnika tego artykułu. Explanatio regulae sancti Benedicti ${ }^{5}$ powstało w la-

\footnotetext{
${ }^{4}$ Hildegarda z Bingen, Wyjaśnienie Symbolu Św. Atanazego, 59.

${ }^{5}$ Św. Hildegarda z Bingen, Komentarz do Reguly św. Benedykta, wstęp, tłum., oprac. Małgorzata Kowalewska, Studia Hildegardiana Sariensia 5 (2018): 25-57. Przy okazji chcę zwrócić uwagę Czytelników na zeszyt naukowy festiwalu Fide et Amore, czyli wychodzące regularnie od 2014 r. Studia Hildegardiana Sariensia, w których są publikowane liczne artykuły związane z osobą i twórczością Hildegardy, przekłady fragmentów jej dzieł oraz inne artykuły (w tym wielu autorów zagranicznych) dotyczące szeroko rozumianej twórczości religijnej i działalności religijnej, zwłaszcza związanej z muzyką. Zeszyty są związane z odbywającym się corocznie Festiwalem Fide et Amore, którego dyrektorem i spiritus movens jest ks. dr Wiesław Hudek. To dzięki jego staraniom w trakcie jednej z edycji tego Festiwalu miała miejsce z Żorach, w Katedrze pod wezwaniem św. Jana, polska premiera moralitetu Hildegardy Ordo virtutum, wykonanego przez grupę polskich śpiewaczek kultywujących muzykę dawną Flores Rosarum pod kierunkiem s. Susi Ferfoglii.
} 
tach 1151-1163, po zakończeniu pracy nad pierwszym dziełem wizyjnym, Scivias, które - przedstawione światu zewnętrznemu podczas obrad Synodu w Trewirze (1147) - uczyniło Hildegardę znaną w wielu środowiskach „Starego Średniowiecza”, a przed podjęciem pracy nad kolejną częścią „trylogii”, czyli Liber vitae meritorum. Ciekawa jest już historia powstania tego dziełka. Jest ono odpowiedzią na list, który napisali do Hildegardy mnisi z pewnego zgromadzenia przeżywającego poważne trudności i kryzysy, prowadzące aż do utraty dobrej opinii zakonników. Owe problemy powstały z powodu braku jednolitej reguły, która powinna porządkować tryb ich mniszego życia, oraz z wyraźnego braku właściwego przywództwa i duchowego kierownictwa. Usłyszeli oni o Hildegardzie i skierowali do niej list z prośbą o pomoc w postaci konkretnych rad, jak powinni żyć. W swojej odpowiedzi ksieni poleca życie zgodne z Regułą św. Benedykta, którą przedstawia jako najbardziej odpowiadającą naturze ludzkiej i taką, do której może dopasować się każdy człowiek, uwzględniając własne warunki duchowe, psychiczne i fizyczne. Ta cecha odróżnia Regułę św. Benedykta, ułożoną na podstawie wieloletniego doświadczenia życia mniszego (a zatem nie aprioryczną), od wcześniejszych reguł, zbyt trudnych dla wielu, dzięki czemu to właśnie ona pozwala każdemu człowiekowi podążać drogą duchowego rozwoju. Respons Hildegardy to jeden z jej listów, który z czasem „wyemancypował się" ze zbioru epistolografii i funkcjonuje jako jedno z hildegardiańskich „dzieł mniejszych”. Wyjaśniając zasady życia według Reguły ułożonej przez św. Benedykta, Hildegarda koncentruje się na kilku wybranych zagadnieniach, głównie związanych $\mathrm{z}$ codziennym funkcjonowaniem człowieka należącego do wspólnoty. Nie będę tu referowała poglądów Hildegardy (zainteresowanych czytelników odsyłam do zeszytu 6 Studia Hildegardiana Sariensia), ale ograniczę się do kilku wniosków, które z tego tekstu wynikają. Po pierwsze, warunkiem angażowania się w życie duchowe jest uporządkowanie codziennych zajęć: najpierw trzeba zaprowadzić porządek w codzienności, a potem można oddawać się sprawom związanym z rozwojem duchowym. Po drugie, należy zwracać uwagę (choć nie jest to łatwe) na wzór osobowy, jakim jest Twórca Reguły, którego cechowały takie cnoty, jak: pokora, miłość, bojaźń Boża, czystość, pobożność. Po trzecie, należy zawsze iść drogą umiaru, a to umożliwia Reguła św. Benedykta, bo nie stawia wymagań ani zbyt wysokich (a przez to dla wielu nie do spełnienia), ani zbyt niskich (a przez to niezapewniających rozwoju duchowego). Po czwarte, we wszystkim trzeba uwzględnić możliwości konkretnego człowieka, to znaczy zarówno wysiłek i pracę, jak i środki ascetyczne, racje i rodzaje żywności, jak też nakładane kary, które powinny być dopasowane do stanu zdro- 
wia, wieku, płci, a w przypadku kary także intencji czynu oraz zdolności rozumienia jego istoty i konsekwencji. W duchu chrześcijańskiego realizmu i humanizmu Hildegarda sprzeciwiała się nadmiernej i nieumiarkowanej ascezie, która czyni z człowieka ziemię jałową, niezdolną do rodzenia pożytecznych roślin. Człowiek nieumiarkowany w praktykach ascetycznych nie rodzi właściwych owoców duchowych, może za to stać się zgryźliwy, krytyczny $\mathrm{w}$ stosunku do innych oraz popaść w samozadowolenie i pychę. Po piąte, należy zachować umiar we wszystkim, nawet w modlitwie, która powinna unikać wielosłowia i nie może prowadzić do znużenia i zniechęcenia zbyt długim trwaniem, a także w czuwaniach, a nawet $\mathrm{w}$ milczeniu. Umiar w milczeniu oznacza przyzwolenie na rozmowę. Całkowite milczenie, zalecane jako jeden z aspektów ascezy, Hildegarda uważa za nieludzkie (inhumanum). Humanizm ugruntowany na umiarze i rozwadze to cechy postawy Hildegardy zaprezentowane przy objaśnianiu Reguły św. Benedykta. Ponadto Hildegarda podkreśla wartość, wynikającej z Reguły, gościnności, która jest przejawem afirmacji osoby - drugiego człowieka, a przejawia się szacunkiem wobec starszych i opiekuńczością wobec młodszych. Myślę, że w chaosie i zbieganiu, wśród presji, które wywierane są na nas z wielu stron, w utracie poczucia równowagi i w dużej mierze także sensu życia, przypomnienie także tej zasady, że każdy dzień powinien dzielić się na pracę, odpoczynek i modlitwę, czyli - inaczej mówiąc - na budowanie, mieszkanie (w sensie czynnościowym) i myślenie, może bardzo pomóc w znalezieniu drogi prowadzącej do Nowego Średniowiecza.

Zalecenie, aby nie zaniedbywać $\mathrm{w}$ życiu żadnego $\mathrm{z}$ głównych jego aspektów, czyli pracy, modlitwy i odpoczynku, Hildegarda wiąże z żywą w jej stuleciu ideą naśladowania Chrystusa. Owa idea była wyraźnie wyrażana zarówno przez Hildegardę, jak też Bernarda z Clairvaux, choć najbardziej znane dzieło De imitatione Christi zostało napisane dwa stulecia później. Bernard podkreślał, że Wcielenie Syna Bożego umocniło pozycję człowieka wśród stworzenia, czyniąc $\mathrm{z}$ niego brata Boga. Wspominam o tym, gdyż zalecany podział czynności w ciągu dnia, który najlepiej służy rozwojowi i funkcjonowaniu każdego człowieka, czyli podział na pracę, modlitwę i odpoczynek, Hildegarda uzasadnia faktem, że tak czynił Syn Boży w swoim życiu ziemskim. Ów podział odpowiada strukturze bytu ludzkiego, która obejmuje sfery fizyczną, psychiczną i duchową.

Idea humanizmu chrześcijańskiego jest trwale obecna w myśli Hildegardy. Wystarczy zwrócić uwagę na te jej wypowiedzi, które określają stosunek duszy do ciała. Wprawdzie poglądy Hildegardy na temat człowieka 
są sformułowane pod wpływem platonizmu i neoplatonizmu, to znaczy dusza i ciało są uznane za dwie różne substancje, to związek między nimi Hildegarda postrzega jednak jako ścisły, konieczny i w gruncie rzeczy korzystny. Ciało bez duszy jest martwe, ale dusza bez ciała jest pozbawiona możliwości wywierania wpływu i działania w świecie materii, a to ostatnie jest zadaniem człowieka, który został stworzony jako dusza i ciało (z tym że ciało pierwszego człowieka miało charakter energii, a jego natura uległa przemianie wskutek grzechu pierworodnego). Hildegarda zdaje sobie sprawę, jak dalece skomplikowana jest relacja duszy i ciała. Właściwa relacja polega nie tyle na równowadze, ile na pewnej przewadze duszy nad ciałem, $\mathrm{z}$ jednoczesną jednak troską o potrzeby ciała. Hildegarda jest więc przeciwniczką skrajności i głosicielką zasady umiaru, co jest widoczne także w jej języku, gdyż wyrażenia aequalis mensura, recta mensura są w jej pismach pojęciami kluczowymi, pojawiającymi się także w związku z tematem relacji duszy i ciała. Właściwa relacja polega na tym, że dusza wychowuje swoje ciało i uczy je odczuwać zadowolenie nie tylko z tych czynności, które są związane z jego własnymi pożądaniami, ale także czynnościami i doznaniami duszy. Ciało jednak często stawia opór duszy i nie chce uczestniczyć $\mathrm{w}$ realizowaniu jej pragnień lub w jakichś praktykach ascetycznych. Wówczas dusza postępuje z ciałem jak matka, która uspokaja płaczące dziecko ${ }^{6}$.

Wiele uwagi Hildegarda poświęca też takim sytuacjom, gdy dusza ulega skłonnościom ciała i po dłuższej lub krótszej walce z pokusami płynącymi z jego strony ostatecznie traci nad nim panowanie, co staje się przyczyną upadku człowieka. Te dwie różne natury (substancje), którymi są dusza i ciało, są tak silnie złączone w jednym bycie, że nigdy nie może zaistnieć sytuacja, iż jedna z nich czyni coś bez udziału drugiej. Gdy więc do głosu dochodzą w człowieku popędy ciała, to nie mogą one zostać zrealizowane bez

\footnotetext{
${ }^{6}$ Hildegarda tak to przedstawia: „Dusza wspiera ciało, a ciało wspiera duszę, ponieważ przez duszę i ciało urzeczywistnia się wszelakie działanie. Dusza ożywa ciało i wraz z nim dokonuje dobre i święte dzieła. Lecz ciało często odczuwa niechęć do współdziałania $\mathrm{z}$ duszą, dlatego dusza przymusza je wówczas i niejako uczy odczuwać zadowolenie, tak jak matka sprawiająca, że płaczące dziecko zaczyna się śmiać. Dzięki temu ciało wraz z duszą dokonuje dobrych czynów, aczkolwiek są one z pewną domieszką grzechu. Dusza, ponieważ jest w swym działaniu podtrzymywana dłonią Boga, wytrzymuje to, by ciało nie uległo zniszczeniu, ponieważ, tak jak ciało żyje dzięki duszy, tak dusza ożywa i rozwija się wykonując wraz z ciałem dobre czyny. Człowiek bowiem, wykonując małe dobre dzieła, wznosi się do góry, niczym wschodzące Słońce. I tak jak Słońce po upływie połowy dnia zaczyna się zniżać, tak i dusza pod wpływem ciała, z którym współodczuwa. Ale tak jak Księżyc wciąż jest na nowo zapalany przez Słońce, aby nie zgasł, tak i ciało ludzkie jest podtrzymywane siłami duszy, by nie uległo zniszczeniu”. HiLDEGARDis Bingensis Liber divinorum operum, CCCM 92, ed. Albert Delorez i Peter Dronke (Turnhout: Brepols, 1978), I, 4. (Tłum. własne - M.K.).
} 
uczestnictwa duszy - choćby $\mathrm{z}$ tego powodu, że to dusza napełnia ciało życiem, sprawiając, iż jest ono w stanie dokonywać określonych aktów. Tak więc dusza, nawet wbrew własnej woli i własnym dążeniom, uczestniczy w aktach spełnianych przez ciało. Sama jednak dusza nie jest w stanie bez udziału ciała realizować swych wzniosłych celów ani nawet dać im wyrazu. Na przykład nie może śpiewać na cześć Boga. Gdy jednak dusza da się zdominować ciału i przez to zostanie wplątana w jakąś grzeszną sytuację, to aczkolwiek w tym grzechu uczestniczy, bo nie była dość silna, by oprzeć się ciału, to jednak uczestnicząc w grzechu, nie doznaje radości, ale odczuwa wyrzuty sumienia, te zaś jakoś wpływają na ciało, które także nie doświadcza spodziewanych radości. Dusza zatem wplątana w grzech ciała przeszkadza ciału i - jak powie Hildegarda — człowiek w tym grzesznym akcie nie cieszy się, ale jeszcze w trakcie realizacji tego aktu zaczyna odczuwać jego gorycz.

Możliwa jest też taka sytuacja, że dusza, dążąc do Boga, zaniedbuje potrzeby ciała i prowadzi do jego wyniszczenia. Taka sytuacja także nie jest przez Hildegardę ani pochwalana, ani akceptowana. Hildegarda wyraźnie stwierdza, że dusza powinna dbać o swoje ciało tak, aby jego potrzeby (konieczności) były zaspokojone, nawet jeśli ich realizacja zawiera pewną „domieszkę" grzechu. Sytuacje, że ciało jest poddane przez duszę bardzo restrykcyjnej dyscyplinie, Hildegarda uważa za szkodliwe także dla duszy, bo mogą się wiązać z przekonaniem o osiągniętej (lub bardzo bliskiej) własnej doskonałości moralnej, a to jest dobry wstęp dla rozwoju głównej wady moralnej - pychy. Ponadto Hildegarda zauważa, że ludzie nadmiernie wyniszczeni, poprzez zaniedbywanie potrzeb ciała, nie stają się doskonali, ale twardzi i nieczuli dla innych.

Człowieka, który zaniedbuje konieczności ciała, Hildegarda porównuje do ziemi, która została zbyt głęboko przeorana pługiem i dlatego stała się jałowa, a innym razem do ziemi, która została zalana ulewą, co sprawiło, że nie mogą na niej zakwitnąć kwiaty ani zboża, a tylko ewentualnie chwasty. W liście do pewnego pustelnika napisała: „Ulewny deszcz niszczy dobrą woń roślin i sprawia, że bujne rosną jedynie bezużyteczne trawy. Umiarkowany zaś deszcz daje wzrost pożytecznym ziołom o pięknym aromacie. Tak też [działa] umiarkowana asceza, stosowana rozumnie według zasad św. Benedykta i świętych ojców, którzy uczyli się od Ducha Świętego. Sprzyja ona duszy i ciału. Ale przez nieumiarkowaną ascezę przebiegle rozwija się pycha i szydercza próżna chwała, a umysł często jest upokarzany przez obciążające go nieczyste myśli. Jest jednak oczywiście dobre, by zapobiegać pijaństwu oraz nadmiarowi jedzenia i napojów, ale też pokrzepienie zgodne $\mathrm{z}$ Regułą jest dobre i konieczne. I tak jak dzieci dostają 
najpierw mleko, a następnie pokarm stały, tak też silni i słabi powinni otrzymywać stosowne dla nich pokarmy"7. Współcześnie wydaje się dominować antropologia oparta na błędzie naturalizmu i związana $\mathrm{z}$ nią permisywna pedagogika. Efektem jest prawie powszechne zapomnienie o konieczności zachowania właściwej proporcji między potrzebami ciała i pragnieniami ludzkiej duszy, które zresztą kultura współczesna sprowadza do poziomu jedynie estetyki (o ile nie mówimy o tak zwanej kulturze popularnej, gdzie znajdujemy się jeszcze niżej), a także porzucenie myśli o konieczności samowychowywania, co oznacza także rozwijanie sprawności moralnych. Dlatego, gdy rozumie się konieczność zmiany postaw i odrzucenia permisywizmu, konsumpcjonizmu i bierdiajewowskiego mamonizmu, dobrze jest sięgnąć po Hildegardę. W tym miejscu należy zauważyć, że tak właśnie się dzieje, o czym świadczy między innymi popularność połączonych z rekolekcjami postów według zaleceń św. Hildegardy. Są one organizowane w wielu krajach, w tym też w Polsce, co moim zdaniem, świadczy o szerokiej recepcji pewnego aspektu myśli Hildegardy. Zaczynając od postu, przechodzi się na ogół do spraw związanych z jej myślą, a jest to myśl chrześcijańska (katolicka). Tym samym współczesny człowiek, nawet gdy zaczyna od troski o swe ciało i jego zdrowie, przechodzi do troski o sprawy duszy. Zainteresowanie dietą zgodną $\mathrm{z}$ zaleceniami Hildegardy idzie w parze z rozwijającym się zainteresowaniem jej medycyną, która jest silnie oparta na tradycjach medycyny klasztornej. Oznacza to zwracanie się do natury jako źródła środków poprawiających zdrowie zarówno w zakresie prewencji, jak i terapii. Zarówno dietetyka, jak i medycyna Hildegardy prowadzą do odzyskania harmonii w ciele, duszy, a także $\mathrm{w}$ duchu, kierując wszystkie poziomy życia ludzkiego w stronę harmonii z innymi ludźmi i harmonii z Bogiem.

\section{MEDYCYNA HILDEGARDY}

Medycyna Hildegardy nawiązuje do tradycji hipokratejsko-galenowskiej i tradycji benedyktyńskiej medycyny klasztornej. W tym artykule chcę zwrócić uwagę na jedną z idei Hildegardy, która wydaje się nader istotna i aktualna, ponieważ odnosi się do etyki badań naukowych. Jest to idea dobrej i złej wiedzy ${ }^{8}$. Właściwie to od przedstawienia tej idei chyba należałoby roz-

\footnotetext{
${ }^{7}$ Hildegardis Bingensis Epistolarium, I-II, ed. Lieven van Acker, CCCM 91A-B (Turnhout: Brepols, 1991-1993), 528, Epistola 249. (Tłum. własne - M.K.).

${ }^{8}$ Hildegardis Bingensis Liber divinorum operum, 73; Hildegardis Bingensis Liber vitae meritorum, ed. Angela Carlevaris, CCCM 90 (Turnhout: Brepols, 1995), 139; Hildegardis Bin-
} 
poczynać wszelkie rozważania dotyczące jakiejkolwiek działalności człowieka związanej z poznaniem i działaniem. Hildegarda w swoich pismach często wymienia dwa rodzaje wiedzy: dobrą (scientia bona) i złą (scientia mala). Żaden z tych rodzajów wiedzy nie ma charakteru czysto spekulatywnego - teoretycznego, ale zawsze poznanie związane jest z praxis, czyli działaniem. Człowiek, zdobywając wiedzę, zdobywa jednocześnie moc działania, czyli spełniania określonych czynów. Podstawą dobrej wiedzy jest zrozumienie ontycznej sytuacji człowieka, czyli oparcie się na właściwej filozofii i teologii, bo tylko te dziedziny pozwalają tę sytuację właściwie rozpoznać, a brak refleksji nad człowiekiem skutkuje bardzo poważnymi ograniczeniami intelektualnymi. Chodzi o poznanie prawdy o miejscu człowieka w świecie, jego prawdziwych możliwościach, jego wielkości, ale też przygodności bytowej, skończoności i ograniczoności, o świadomość istnienia granic, których przekraczać nigdy nie wolno, chociaż technicznie można je już przekraczać. Dobra wiedza pomaga człowiekowi dostosować się do świata, patrzeć na innych jak na osoby i tak je traktować. Musi się ona opierać na cnotach moralnych i pozostawać w ścisłym związku z etyką, która rozpoznaje powinności moralne, normy oraz ukazuje nieprzekraczalne granice. Dobra zatem wiedza musi mieć podstawy w ujęciach uniwersalnych. Zła wiedza zaś to taka, która nie rozpoznaje właściwie ontycznej sytuacji człowieka, a stąd płyną katastrofalne błędy. Co do złej wiedzy, to już samo takie sformułowanie może dziś budzić zdziwienie, ponieważ wciąż słyszymy, że informacja jest najważniejsza, społeczeństwo ma być „oparte na wiedzy" itd., natomiast to, co można przeczytać u Hildegardy na temat złej wiedzy, da się odnieść nieomal bez żadnych unowocześnień i interpretacji do współczesnych rozważań na temat etyki naukowej, w tym badań związanych z pewnymi dziedzinami medycyny oraz do pewnych koncepcji filozoficzno-technologicznych, jak np. transhumanizm. Poglądy Hildegardy w tej kwestii mogą być jak najbardziej głosem w naszych współczesnych dyskusjach na temat granic ludzkiego działania i do tego w najbardziej drażliwych tematach, takich jak: transplantologia (myślę tu o przeszczepach od dawców żywych, wobec których orzeka się tak zwaną śmierć pnia mózgu, o wycenie wartości ludzkiego ciała, o nielegalnym handlu organami), zapłodnienie pozaustrojowe, surogacja, aborcja, eutanazja, zmiana operacyjna płci, wpływ firm i koncernów farmaceutycznych, wymuszane szczepienia, medykalizacja ży-

GENSIS Epistolarium, I-II, 259, Epistola 103. Por. Małgorzata KowALEwSKA, „Związek etyki i medycyny w koncepcji Hildegardy z Bingen", w: Humanizm a medycyna, red. Alina Bernadetta Jagiełłowicz (Wrocław: Wydawnictwo Naukowe Oficyna Wydawnicza Arboretum, 2013), 90-94. 
cia i chemizacja terapii medycznych. Czy sam fakt, że coś jest możliwe do przeprowadzenia albo, że ktoś czegoś bardzo chce, wystarczy jako argument „za”? Hildegarda przemawia do nas z odległego stulecia i zwraca uwagę na to, że podstawą tego, co ona nazwała złą wiedzą, jest pycha - wada, która odrzuca prawdę, nie akceptuje granic, prowadzi do utraty kryteriów pozwalających oceniać prawdziwą wartość świata i granic własnych pragnień. Zła wiedza to dążenie do stałego przekraczania granic, by zrealizować roszczenia, które ukrywają się pod płaszczykiem „dobra ludzkości” lub jakimś podobnym szyldem. Zła wiedza jest przez Hildegardę kojarzona z pewną wadą moralną, którą nazywa ona malefacium, co można oddać polskim słowem „czarnoksięstwo”. Jest to postawa związana z pragnieniem całkowitego opanowania przyrody i pokonania - dzięki nauce - praw natury. Przejawia się dążeniem do uzyskania władzy nad światem, co musi być związane z łamaniem rządzących naturą praw. Jest to próba wykorzystywania świata dla własnych celów i opanowania praw natury nawet w sprawach ostatecznych, jak na przykład śmierć ${ }^{9}$. Z taką postawą zawsze wiąże się przedmiotowe traktowanie innych ludzi (np. jako rezerwuar zamiennych organów). Jest to więc poważne skażenie ducha pod pozorem zdobywania wiedzy, poprawy życia i zapobiegania złu. Dlatego, i to głosi Hildegarda, bardzo ważne jest, by badacz zadawał sobie stale pytanie, dokąd dąży, jakie są jego właściwe cele, co nim kieruje, jakie są naprawdę jego intencje ${ }^{10}$.

Hildegarda nie występuje przy tym przeciwko nauce, nie neguje ani nie oskarża ludzkiego dążenia do poznania świata, ale dostrzega poważne niebezpieczeństwo $\mathrm{w}$ postawie dążącej do podporządkowania sobie świata za wszelką cenę. Uczona z Bingen, określająca ową postawę jako „czarnoksięstwo", jest poprzedniczką dwóch bardzo ważnych dla kultury europejskiej dzieł literackich. Mam na myśli Tragiczne dzieje doktora Fausta Christophera Marlowa i Fausta Johanna Wolfganga Goethego. One to przecież opisują tę samą postawę, zawarty z jej powodu „pakt z diabłem” i tragiczne tego skutki. Poszukiwacze złej wiedzy nie są jednak (wbrew własnemu mniemaniu) autonomiczni w swych działaniach (wszystkie one odbywają się pod hasłem wolności nauki i autonomii człowieka, co jakoby przeciwstawia się ograniczeniom narzucanym przez realistyczną filozofię i teologię, a zwłaszcza religię), ale podążają za swym przewodnikiem, którym jest - według Hildegardy - diabeł. Posiada on wiedzę o całym wszechświecie, wie wszystko o stworzeniach (scientia omnium creaturarum), ale nie akceptuje swego

\footnotetext{
${ }^{9}$ Por. Hildegardis Bingensis Liber vitae meritorum, 221-223,

${ }^{10}$ Hildegardis Bingensis Epistolarium, I-II, 255, Epistola 99.
} 
drugiego miejsca, miejsca po Bogu. Chce być pierwszym, a człowieka przekonuje, że to właśnie człowiek jest „drugim bogiem” i dlatego wolno mu wszystko $^{11}$. Dodam, że według Hildegardy te dwa rodzaje wiedzy w żadnym wypadku nie uzupełniają się ani nie ,inspirują”, ale zawsze się wykluczają.

\section{HILDEGARDA A EKOLOGIA}

Do ważnych aspektów współczesności należą idee szeroko rozumianej ekologii, które podejmują zarówno filozofowie (przykładem może być bardzo interesująca książka Zielona filozofia Rogera Scrutona ${ }^{12}$ ), jak i przedstawiciele innych dyscyplin nauki, a także sztuki. W kontekście ekologii również należy wspomnieć Hildegardę z Bingen, dlatego, że jej pisma są świadectwem prawdziwej fascynacji przyrodą i pięknem świata stworzonego przez Boga. Przypomina ona o miejscu i roli człowieka wśród pozostałych stworzeń oraz o odpowiedzialności człowieka za stan natury. Poglądy Hildegardy na temat przyrody są umieszczone w kontekście wizji całej rzeczywistości i są świadectwem znajomości dzieł poprzedzających ją autorów oraz ujawniają jej własną wiedzę zdobytą dzięki obserwacjom otaczającego ją świata. We wszystkich swoich pismach Hildegarda pisze o świecie flory i fauny, nadaje im funkcje symboliczne i przedstawia ich znaczenie oraz przydatność dla człowieka. Opisuje zwyczaje zwierząt, istniejących realnie, ale także zwierząt fantastycznych. Zwierzęta są też dla niej dobrymi ilustracjami pewnych cech lub postaw ludzkich. Hildegarda przedstawia człowieka jako zajmującego centralne miejsce w świecie stworzonym, ale pisze też o nim jako o „kronice stworzenia”, porównując człowieka do skrawka pergaminu, na którym ktoś streścił całą historię świata. Zadanie człowieka definiuje jako współpracę z Bogiem, reprezentowanie Boga wobec pozostałego stworzenia, sprawowanie opieki nad zwierzętami i uprawę ogrodu, którym jest świat. Nazywa człowieka „światłem”, wokół którego gromadzą się niższe od niego zwierzęta, ale podkreśla zarazem, że człowiek owe zwierzęta ma kochać, otaczać opieką, także dlatego, że bez nich nie może żyć: „Człowiek nie mógłby żyć, gdyby nie było w nim układu połączonych żył, i tak samo nie mógłby żyć, gdyby nie było pozostałych stworzeń" ${ }^{13}$, a także: „Człowiek jest niczym światło dla zwierząt przebywających na ziemi,

\footnotetext{
${ }^{11}$ Ibidem, 281, Epistola, 113.

${ }^{12}$ Roger Scruton, Zielona filozofia. Jak poważnie myśleć o naszej planecie, thum. Justyna Grzegorczyk i Rafał P. Wierzchosławski (Poznań: Zysk i S-ka, 2017).

${ }^{13}$ Hildegardis Bingensis Liber divinorum operum, 257. (Tłum. własne - M.K.).
} 
które częstokroć przybywają do niego i które darzą go wielką miłością. Także i on pilnie poszukuje tych zwierząt, które kocha" ${ }^{14}$. W jednym z listów Hildegarda nazywa świat „ogrodem rozkoszy” (hortus deliciarum), pełnym wspaniałych kwiatów i ziół, które człowiek powinien poznawać, podziwiać i chronić. Jeśli tego nie robi, sam sprowadza się do poziomu ryjących w ziemi robaków ${ }^{15}$. Ten podziw dla całego świata $\mathrm{i}$ uznanie wartości wszystkich stworzeń nie oznacza, że można je uważać wszystkie za równe sobie, przeciwnie: w świecie panuje hierarchia, a na jej szczycie, w porządku świata przyrody, znajduje się człowiek.

Z tematem ekologii wiąże się wątek odpowiedzialności człowieka za zniszczenie przyrody. Dziś ten wątek jest bardzo silnie podkreślany, a rozwiązanie problemów związanych $\mathrm{z}$ zanieczyszczeniem środowiska wydaje się niemożliwe. To jeden $\mathrm{z}$ istotniejszych problemów, z którym będzie musiało sobie poradzić ewentualne „Nowe Średniowiecze”. I tu znowu przywołać możemy Hildegardę, która $\mathrm{w}$ swych dziełach podkreślała związek między człowiekiem a światem, tak mocny, że czyny człowieka przyczyniają się do zmian w przyrodzie. Są to między innymi zmiany klimatu, nietypowe dla poszczególnych pór roku pogody, wysychanie lasów, itp. Zależność między sposobem życia człowieka, jego zachowaniem a stanem fizycznym kosmosu jest ścisła. Człowiek, naruszając prawa natury, wprowadza zakłócenia w normalny (,zwyczajny”) tok rzeczy. Natura odpowiada dziwnymi zjawiskami (suszami, powodziami, trzęsieniami ziemi, zarazami, zmianą właściwości pór roku, bezpłodnością pól). Jest to odpowiedź natury na ludzkie działania wbrew naturze. Tę odpowiedź Hildegarda określa jako planctus naturae -

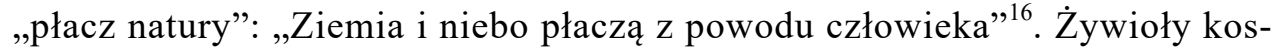
miczne płaczą, ponieważ postępowanie człowieka (jego grzechy) zakłócają ich porządek: nie pozwalają iść właściwą drogą. Grzechy, o których myśli Hildegarda, to nie nadmierna eksploatacja środowiska (jak można by myśleć w dzisiejszych kategoriach), ale morderstwa, zabójstwa, czyny homoseksualne, kazirodztwo, oszustwa, czyli grzechy ciężkie. Dzisiejsze grzechy wobec natury wynikają z postawy, którą Bierdiajew nazwał „mamonizmem”, każącej na wszystko patrzeć przez pryzmat zysku materialnego. Hildegarda mówi, że natura płacze z powodu człowieka, z powodu jego działań idzie nie tą drogą, co trzeba, ale zdaniem Hildegardy nieustannie zwrotnie oddziałuje na człowieka. W ten sposób błędne koło się zamyka, a skutki działań czło-

\footnotetext{
${ }^{14}$ Ibidem, 251. (Tłum. własne - M.K.).

${ }^{15}$ Hildegardis Bingensis Epistolarium, I-II, 51, Epistola 17.

${ }^{16}$ Hildegardis Bingensis Causae et curae. Liber I, ed. Paulus Keiser (Leipzig: B.G. Teubner, 1903), 18; HildEGARDIS BingENSIS Liber divinorum operum, 124.
} 
wieka wracają do niego. Motyw „płaczu natury” świadczy nie tylko o czymś, co można by określić mianem „wrażliwości ekologicznej”, ale o uniwersalizmie spojrzenia dwunastowiecznej mniszki. I dodajmy: nie tylko jej jednej, bo przecież całej jej epoki - średniowiecza. Na marginesie dodam, że ten sam motyw występuje u wielu autorów owego czasu, między innymi u Allana z Lille, autora utworu De planctu naturae" ${ }^{17}$, dalej w poemacie Wilhelma z Lorris i Jan z Meun Le Roman de la Rose, czyli Powieść o róży ${ }^{18}$, w De universitate mundi Bernarda $\mathrm{z}$ Tours oraz w dziele Mechtyldy z Magdeburga Das fließende Licht der Gottheit, czyli Strumień światta Boskości ${ }^{19}$. Z pewnością Hildegardę możemy uznać, obok św. Franciszka, za patronkę ekologii.

\section{HILDEGARDA A MUZYKA}

Hildegarda wkroczyła do XXI stulecia nie tylko dzięki swojej teologii i filozofii, nie tylko dzięki diecie i medycynie, ale także dzięki swojej sztuce, dzięki muzyce. Jest ona nie tylko autorką dzieł o tematyce teologiczno-filozoficznej, ale jest także poetką i kompozytorką. Zachował się zbiór ponad siedemdziesięciu pieśni jej autorstwa, które stały się dla nas dostępne dzięki pracy uczonych badających rękopisy, a także dzięki artystom, którzy zafascynowani muzyką dawną, nagrywali i nagrywają płyty, organizują koncerty, dzięki czemu owa muzyka jest słuchana także przez współczesnych odbiorców. Hildegarda pisała pieśni o wzniosłej tematyce, komponowała ich melodie i sama je wykonywała. Utwory te można dzielić na różne rodzaje: hymny, responsoria, sekwencje, pieśni, ale wszystkie są muzyką chorałową, odzwierciedlającą w jakimś możliwym do uzyskania stopniu muzykę, która brzmi w samym niebie. Umiłowanie muzyki jest zakorzenione w duszy człowieka, bo ludzka dusza zawiera w sobie harmonię i ,jest symfoniczna”. Jest ono także wyrazem ludzkiej tęsknoty do Raju, miejsca, które zostało utracone wskutek pierworodnego grzechu. Jest związane z uczestniczeniem człowieka w muzyce świata. Dzięki muzyce człowiek nie tylko doświadcza wrażeń estetycznych, ale przede wszystkim chwali Boga „niemal tak samo jak wielbią Go ptaki, kwiaty i niebiosa" ${ }^{20}$ — te słowa

\footnotetext{
${ }^{17}$ Zob. Alanus ab Insulis, De planctu naturae, PL 210, kol. 51-110.

${ }^{18}$ Wilhelm z Lorris i Jan z Meun, Powieść o róży, tłum. M. Frankowska-Terlecka i T. Giermak-Zielińska (Warszawa: Państwowy Instytut Wydawniczy, 1997), 394-396.

${ }^{19}$ Mechtylda z Magdeburga, Strumień światła Boskości, tłum. Polikarp Jan Nowak, Źródła monastyczne 31, t. 2 (Kraków: Wydawnictwo Benedyktynów Tyniec, 2004), 100

${ }^{20}$ C[live] S[taples] Lewis, „O muzyce kościelnej”, w: Rozważania o chrześcijaństwie, thum. Zbigniew Kościuk (Warszawa: Logos, 2020), 114.
} 
popularnego autora i znawcy literatury Clive'a Staplesa Lewisa brzmią jak cytat z pism Hildegardy, która uważała, że każdy byt, włącznie z czterema żywiołami, posiada właściwy sobie ton, którym włącza się w muzykę świata, chwaląc $\mathrm{w}$ ten sposób Stwórcę. Szczególnie pięknym rodzajem muzyki, która $\mathrm{z}$ pewnością powinna być $\mathrm{w}$ przywrócona na stałe $\mathrm{w}$ kościele, jest muzyka chorałowa, o której Roger Scruton tak pisze: „Śpiew chorałowy należy do łatwo rozpoznawalnych i frapujących dla ucha, ale czy można go nazwać melodią? [...] Chorał charakteryzuje się innym rodzajem porządku niż melodia - to fragment nieskończoności, który w założeniu nie ma początku ani końca. Płynie on nieustannie, a to, co słyszymy jako początek, jest tylko punktem, w którym pojawiają się głosy. Odbieramy przepływ chorału jako istniejący przed wejściem głosów, które jedynie «przejmują» melodię płynącą w kosmosie nieskończenie i najczęściej w milczeniu. Chorał daje nam jeszcze zatem inny pogląd na zjawisko melodyczne, jako fenomen, który zdaje się nie należeć DO NAS, lecz istnieć odwiecznie w odrębnej rzeczywistości. Istnieje w rzeczy samej nie jako konkretny byt, ale jako nieskończony śpiew, którego jedynie fragmenty mogą zostać wychwycone przez skończone i ograniczone stworzenia. Jest to oczywiście część istoty i sensu chorału, a zarazem przyczyna, dla której zarówno ten typ melodyki, jak i chroniąca go tradycja wykonawcza, wielokrotnie przez lata tracona i odzyskiwana, mają dla nas tak wielkie znaczenie" ${ }^{21}$.

W dzisiejszych czasach, gdy muzyka przeżywa kryzys widoczny na wielu płaszczyznach (nie ma miejsca w ramach tego artykułu na przedstawianie tego zagadnienia), a większość ludzi zalewana jest tak zwaną muzyką popularną, propagowanie muzyki poważnej, zwłaszcza tej tworzonej w dawnych czasach, jest rzeczą ze wszech miar ważną. Dlatego nie można przeoczyć i tego faktu, jakim jest wzrastające zainteresowanie tą częścią spuścizny Hildegardy. Muzyka jest tą dziedziną sztuki, której nie wystarczy analizować i opisywać. Podobnie jak malarstwo, które trzeba zobaczyć, bo nie wystarczy czytać o obrazach, tak muzykę trzeba usłyszeć, musi więc zostać wykonana. Jako pierwsza muzykę Hildegardy udostępniła wytwórnia Deutsche Hermonia Mundi, przygotowując nagrania pieśni w wykonaniu zespołu (dziś już chyba nieistniejącego) Sequentia. Dziś mogę już napisać, że mamy także pierwsze polskie wykonanie śpiewów Hildegardy (jej muzyka to w przeważającej mierze muzyka wokalna) utrwalone na nagraniu płytowym. Nagrania dokonał żeński zespół wokalny Flores Rosarum, a płyta nosi tytuł $\mathrm{Ad}$

\footnotetext{
${ }^{21}$ Roger SCRUTON, Muzyka jest ważna, tłum. i red. Katarzyna Marczak (Kraków: Fundacja InCanto, 2020), 29.
} 
caelestem Jerusalem perducando i jest częścią monografii po tym samym tytułem ${ }^{22}$.

W artykule wskazałam kilka spośród wielu faktów świadczących o atrakcyjności idei „Nowego Średniowiecza” związanych z osobą Hildegardy z Bingen. Na zakończenie chciałam wskazać na jeszcze inną formę jej obecności w naszych czasach. Mam na myśli popularyzowanie jej osoby, twórczości, diety, medycyny, a także filozofii i teologii przez działające w Polsce Towarzystwa Przyjaciół Hildegardy. Prowadzą one działalność wydawniczą, naukową, dydaktyczną, organizują rekolekcje, posty, kongresy i konferencje poświęcone Hildegardzie, kulturze chrześcijańskiej i średniowieczu, w kontekście spraw i problemów naszej współczesności. Stanowi to swoisty fenomen kulturowy, a powstałe „nisze” gromadzą osoby zainteresowane własnym rozwojem wewnętrznym, afirmacją wartości osobowych i tradycyjnych wartości kultury europejskiej.

\section{BIBLIOGRAFIA}

Hildegarda z Bingen. Komentarz do Reguly św. Benedykta. Wstęp, tłum., oprac. Małgorzata Kowalewska. Studia Hildegardiana Sariensia 5 (2018): 25-59 .

Hildegarda z Bingen. Wyjaśnienie Symbolu Św. Atanazego. Wstęp, przekład i oprac. Małgorzata Kowalewska. Hildegardiana opera minora, red. Blanka Szymańska. Ełk: Adalbertinum 2015.

Hildegardis Bingensis Causae et curae. Liber I, ed. Paulus Keiser. Leipzig: B.G. Teubner, 1903.

Hildegardis Bingensis Epistolarium. I-II, ed. Lieven van Acker. Corpus Christanorum Continuatio Mediaevalis 91A-B. Turnhout: Brepols, 1991-1993.

Hildegardis Bingensis Liber divinorum operum, ed. Albert Delorez i Peter Dronke. Corpus Christanorum Continuatio Mediaevalis 92. Turnhout: Brepols, 1978.

Hildegardis Bingensis Liber vitae meritorum, ed. Angela Carlevaris. Corpus Christanorum Continuatio Mediaevalis 90. Turnhout: Brepols, 1995.

Alanus ab Insulis [Alan z Lille]. De planctu naturae. PL 210, kol. 51-110. Także: Liber de planctu naturae. http://www.thelatinlibrary.com/alanus/alanus1.html. Przekład angielski: The Complaint of Nature. https://sourcebooks.fordham.edu/basis/ alain-deplanctu.asp.

BAlter, Lucjan. Atanazjański symbol wiary. W: Encyklopedia katolicka, t. 1, kol. 1025. Lublin: Towarzystwo Naukowe KUL, 1973.

Bierdiajew, Mikołaj. Nowe Średniowiecze, thum. Marian Reutt, Meandry kultury (Kraków: Wydawnictwo Vis-à-vis Etiuda, 2019; przedruk za wydaniem: Poznań: Towarzystwo Wydawnicze „Głosy”, 1936).

\footnotetext{
${ }^{22}$ Małgorzata Kowalewska, Anita Pyrek-Nackiewicz i Susi Ferfoglia, Ad caelestem Jerusalem perducando (Kraków: Uniwersytet Papieski Jana Pawła II, 2020).
} 
KowalewsKa, Małgorzata. „Związek etyki i medycyny w koncepcji Hildegardy z Bingen”. W: Humanizm a medycyna, red. Alina Bernadetta Jagiełłowicz, 81-97. Wrocław: Wydawnictwo Naukowe Oficyna Wydawnicza Arboretum, 2013.

Kowalewska, Małgorzata, Anita Pyrek-Nąckiewicz i Susi Ferfoglia. Ad caelestem Jerusalem perducando. Kraków: Uniwersytet Papieski Jana Pawła II, 2020.

LewIS, C[live] S[taples]. Rozważania o chrześcijaństwie. Tłum. Zbigniew Kościuk. Warszawa: Logos, 2020.

Mechtylda z Magdeburga. Strumień światła Boskości. Tłum. Polikarp Jan Nowak. Źródła monastyczne 31. Kraków: Wydawnictwo Benedyktynów Tyniec, 2004.

SCRUTON, Roger. Zielona filozofia. Jak poważnie myśleć o naszej planecie. Tłum. Justyna Grzegorczyk i Rafał P. Wierzchosławski. Poznań: Zysk i S-ka, 2017.

Scruton, Roger. Muzyka jest ważna. Tłum. i red. Katarzyna Marczak, Kraków: Fundacja InCanto, 2020.

Wilhelm z LoRRIS i JAN z MeUn. Powieść o róży. Wybór, przekład ze starofrancuskiego i wstęp Małgorzata Frankowska-Terlecka i Teresa Giermak-Zielińska. Bibliotheca mundi. Warszawa: Państwowy Instytut Wydawniczy, 1997. Oryg. Le roman de la rose par Guillaume de Lorris et Jean de Meung. Édition accompagnée d'une traduction en vers. Précédée d'une Introduction, notices historiques et critiques; suivie de Notes et d'un Glossaire par Pierre Marteau. T. I. Paris, 1878. Project Gutenberg. http://www.gutenberg.org/ebooks/16816.

\section{ZE STAREGO ŚREDNIOWIECZA DO NOWEGO}

Streszczenie

Głównym celem artykułu jest przedstawienie wybranych aspektów funkcjonowania w XX i XXI wieku myśli i twórczości Hildegardy z Bingen. Szerokie zainteresowanie ową twórczością jest $\mathrm{w}$ tym artykule formą prezentacji rosnącej tendencji do wznowienia dawno utraconego duchowego wymiaru życia. Zainteresowanie twórczością i osobą Hildegardy zaczęło wzrastać po okresie prac filologicznych, który przypomniał jej twórczość. Twórczość Hildegardy stała się źródłem inspiracji dla filologów, filozofów, teologów, artystów i muzykologów. Istnieje wiele Towarzystw Przyjaciół Hildegardy, które propagują jej idee. W kontekście dzisiejszego kryzysu kultury jej przestrogi skierowane do duchowieństwa i jej idee filozofii człowieka wydają się bardzo aktualne. W tej dziedzinie idea humanizmu chrześcijańskiego jest szczególnie ważna. Aktualne i ważne są jej poglądy na temat badań naukowych, w szczególności na temat rozróżnienia między dobrą a złą wiedzą (scientia bona, scientia mala). Także idea umiaru i idea relacji człowieka z ziemią. Zapewne z tego powodu jej dietetyka i medycyna są w dzisiejszych czasach tak popularne. Dzięki temu Hildegarda z Bingen ze starego średniowiecza wkracza w nowe średniowiecze, które być może nastąpi.

Przełożyt Stanisław Sarek

Słowa kluczowe: Hildegarda z Bingen; średniowiecze; kryzys kultury; humanizm; ekologia; umiar; wiedza dobra i zła (scientia bona, scientia mala). 


\section{FROM THE OLD MIDDLE AGES TO THE NEW ONES}

\section{Su m m ary}

The main purpose of this article is presentation of chosen aspects which say about functioning of the thought and creation of Hildegard of Bingen in XX and XXI century. Wide interest of this creation is in this article a form of representation of growing tendency of resumption of the long lost spiritual dimension of live. Interest about creation and person of Hildegard started to becoming more popular after the period of philological works which recalled her work. Hildegard's works became source of inspiration for philologists, philosophers, theologians, artists and musicologists. There are many Companies of Friends of Hildegard which propagate her ideas. In the context of today's crisis of culture her admonitions to clergy and her ideas of philosophy of man seems very actual. In this sphere idea of Christian humanism is especially important. Current and important are her opinions about scientific research especially about distinction of good and evil knowledge (scientia bona, scientia mala). Also idea of moderation and idea of human to earth relation. This is probably the reason why dietetics and medicine of her are so popular in this days. Thanks to that, Hildegard of Bingen from old middle ages enters into new middle ages which perhaps will come to be.

Key words: Hildegard of Bingen; middle ages; crisis of culture; humanism; ecology; moderation; good and evil knowledge (scientia bona, scientia mala). 